\title{
THE ANALYSIS OF THEME-RHEME ORGANIZATION ON JOKOWI WIDODO'S SPEECH
}

\author{
Amsaldi Wahyu Kristian Sinulingga ${ }^{1}$, Asnita Hasibuan ${ }^{2}$ \\ *1 Penulis 1 \\ *2 Penulis 2 \\ Mahasiswa Pascasarjana Universitas Sumatera Utara dan Dosen Universitas Katolik Santo Thomas \\ amsaldi@students.usu.ac.id, asnita103hasibuan@gmail.com
}

\begin{abstract}
ABSTRAK
Penilitian ini berjudul “The Analysis of Theme-Rheme Organization on Joko Widodo's Speech" adalah sebuah kajian linguistik berdasarkan dari analisis wacana. Di penilitian ini, objek yang di analisa penliti adalah tema dan rema yang terdapat di pidato Jokowi Widodo. Pidato yang menjadi data di penlitian ini diambil dari Kantor Asisten Wakil Sekretaris untuk Dokumen dan Terjemahan Negara pada 16 April 2019. Teori yang mendukung penelitian ini diambil dari teori Halliday. Berdasarkan teori tersebut, kajian dari tema dan rema berasal dari linguistik fungsional sistemik yang menganilsis bahasa dari fungsi utamanya. Hasil dari penelitian ini terdapat 8 paragraf di dalam pidato. Dari kedelapan paragraph tersebut, terdapat 47 klausa: dari ke 47 klausa tersebut, terdapat $87 \%$ dengan 41 klausa sebagai tema topikal, kedua adalah tema tekstual dengan 11\% dari 5 klausa, terakhir adalah tema interpersonal terdapat 1 klausa dengan persentase $2 \%$
\end{abstract}

Kata Kunci: tema-rema, pidato Jokowi Widodo, analisis wacana

\begin{abstract}
This study entitled as “The Analysis of Theme-Rheme Organization on Jokowi Widodo's Speech is linguistics study viewed from discourse analysis. In this study the object that the researcher analyzed is the theme and rheme that are found in the Jokowi Widodo's speech. The speech as the data of this study is collected from the Office of Assistant to Deputy Cabinet Secretary for State Documents \& Translation on $16^{\text {th }}$ April 2019. The theory supporting in this study is taken from Halliday theory. Based on these theory, the study of theme and rheme is mainly derived from systemic functional linguistic that analyzes language from its main function. The result of this analysis is that 8 paragraphs existed in the speech. From those eight paragraphs there are 47 clauses found: the 47 clauses, there is $87 \%$ with 41 clauses belong to topical themes, the second is textual theme which the percentage is $11 \%$ of 5 clauses, The last is interpersonal theme there is found 1 clauses which the percentage is $2 \%$.
\end{abstract}

Keywords: theme-rheme, Jokowi Widodo's speech, discourse analysis

\section{INTRODUCTION}

As human beings, we always communicate. We use language as one of the devices to convey message that we want to share. Halliday (1994) states that language could be interpreted as a system of meaning, it

ISSN 15421-71667

Volume 2 Nomor 2 Desember 2019 means when people use language, their language acts to produce or construct meaning. Furthermore, Bloor \& Bloor (2004) argue that the ways in which people use language are classified into three; (1) language is used to organize, understand and express our perceptions of the world and of our 
consciousness. It is known as ideational meaning; (2) language is used to enable us to participate in communicative acts with other people, to take roles and to express and understand feelings, attitude and judgments. It is known as interpersonal meaning; (3) language is used to relate what is said (written) to the rest of the text and to other linguistic events. This involves the use of language to organize the text itself and to make language contextually and co-textually relevant. It is realized in lexico-grammar through thematic structure that is known as textual meaning. Thematic structure in English is the idea represented by the constituent at the starting point of the clause. In simple term, a clause begins with a realization of the theme. After that, it is followed by the realization of the rheme, which can be explained as being the rest of the message.

\begin{tabular}{l|l}
\hline She & Is a beautiful girl \\
\hline Theme & Rheme \\
\hline
\end{tabular}

The example above shows that "She" refers to person that is talked about and "is a beautiful girl" as the rest of clause. In addition, it talked about the theme (or it gives us more information about the theme).

To analyze about theme rheme we had to know what it is theme rheme. According to Halliday (2004), the study of theme and rheme is mainly derived from systemic functional linguistic that analyzes language from its main function. Following the terminology of the Prague school of linguists, we shall use the term Theme can be used as the label for this function. The theme is the element which serves as the point of departure of the message; it is that which the clause is concerned. While, Rheme is the remainder of the message in a clause in which Theme is developed, is called in Prague school terminology the Rheme. ISSN 15421-71667

Volume 2 Nomor 2 Desember 2019
According to Halliday (2004), the study of theme and rheme is mainly derived from systemic functional linguistic that analyzes language from its main function. Theme has divided into two parts there are simple and multiple the simple theme is topical and the multiple theme are textual and interpersonal.

Topical theme is theme of clause ends with the first constituent that is either participant, Circumstance or process (Halliday \& Matthiessen, 2004:105). This suggests that the speaker/writer is selecting the desired. Theme that there can be variation in what is chosen as the thematic element in the clause. The Type of theme is presented by a nominal group (e.g., everyone), a prepositional phrase.

Halliday and Matthiessen (2004) stated that textual theme is a theme that includes any combination of continuative (yes, no, well, oh, now), conjunctions (and, because, who, but, etc), conjunctive adjunct (for instance, in addition, likewise). Conjunctive adjuncts are allowed to move freely in a clause whereas conjunctions are constrained in the beginning (Giroux, 1997). Moreover, conjunctives, on the other hand, relate the clause to the preceding text by providing a logical between messages.

According to Paltridge (2006), interpersonal theme refers to an item that comes before rheme which indicates the relation between participants in the text, or the position or point of view that is being taken in the clause. This may include the finite in interrogative clause where it precedes the subject, vocative (personal name used to address), and mood adjuncts (surprisingly, in my opinion, unfortunately) (Halliday \& Matthiessen, 1994). From three type of theme, the researcher want to found it in speech text.

Speech is some utterance with a good structure to convey the people. Usually, Speech use in some event such as speech 
state, speech great day, speech plant spirit, speech event and so forth. A good speech giving a positive impression to audiences. Speech consist of three parts, there are introduction, content and closing;

1) Introduction or opening; introduction contains greeting, honor and thanks giving, respect the form of greeting respectfully. The figures are present in an event and to the audience.

2) Content; content is the most important part of speech, what we will tell all package in a part of contents. Therefore, it need details that information what we will convey don't missed.

3) Closing; closing is consist of hope or prayer that what we will convey can be useful for audience and also contain greeting closing.

\section{METHOD}

This study was used descriptive qualitative method. It was relevant and appropriate study since the study the finding on the worldview through analysis theme-rheme in the Jokowi Widodo's speech text. Descriptive qualitative method is used to describe the finding in detail. According to Nancy Burns and Susan Grove (2003,p.201), Descriptive qualitative method was designed to provide a picture of a situation as it naturally happens. In this research, it was used to describe and analyzed the problem, and to develop theories in detail about the object.

The object of the study of this research will be focused on every clause in the speech text by Jokowi Widodo on Tuesday, April 16, 2019. So the subject of this analysis is clauses in the speech text produced by Jokowi Widodo. The data on this research was speech text that can be interpreted as a sentence and utterance if it was spoken. The data of this study was downloaded from website. The source language was Jokowi Widodo's full speech transcript annotated; by Office of Assistant to Deputy Cabinet Secretary for State Documents \& Translation was post on April 22, 2019 retrived from website https://setkab.go.id/en/remarks-of-presidentjoko-widodo-at-the-halal-park-inaugurationon-16-april-2019-at-the-bung-karno-sportscomplex-gbk-senayan-central-jakarta-jakartaprovince/

The main and primary instrument of a qualitative research was the researcher himself. According to Meleong (2007) the instrument of this study was the researcher himself with his knowledge and other references which was related to the study. In addition, this research used secondary instruments, such as data sheet, table for analysis, and the official script of Jokowi Widodo's speech text.

The research analysis was in any project involve summarizing the mass of data that has been collected and the presenting the results in a way that communicates the most important findings or features. According to Ardhana12 (in Lexy J. Moleong 2002: 103) explains that data analysis was the process of arranging the order of data, organizing it into a pattern, category, and set of basic descriptions. Likewise in this research, to get the main result on this research, researcher will do same technique. The steps in analyzing the data are as follows :

1) Reading

The researcher was reading the whole of speech text to comprehension of this speech text.

2) Segmenting

After reading the speech text, researcher was segmenting the sentences on the paragraph into clauses. 


\section{3) Identifying}

The researcher was identifying the words of each clauses to knowing the types of theme in the clauses.

\section{4) Classifying}

The researcher was classifying the types which found in identification of clause in the speech text, it make easier the reader and researcher saw the result of analysis.

\section{5) Drawing conclusion}

The last procedure, the researcher was drawing conclusion from classification to explain the result of analysis.

\section{FINDINGS}

To find the result of this speech text, the researcher had to analyze the speech text that based on the steps above. After segmenting each clauses and identifying the categories of theme at each clause. The categories of it is found, after that the researcher was classified the categories. In the speech text, the paragraphs has found 8 paragraphs and from it has found 47 clauses. From 56 clauses can found that theme rheme on the Jokowi Widodo in the Halal Park Inauguration on 16 April 2019 at the Bung Karno Sports Complex (GBK), Senayan, Central Jakarta, Jakarta Province speech. The results of theme and rheme of each paragraph can be seen in the following table 1.1 below:

\begin{tabular}{|c|c|c|c|c|c|c|c|c|c|c|}
\hline \multirow[t]{2}{*}{ NO } & \multirow{2}{*}{$\begin{array}{l}\text { Types } \\
\text { of } \\
\text { Theme }\end{array}$} & \multicolumn{8}{|c|}{ Paragraphs } & $\Sigma$ \\
\hline & & 1 & 2 & 3 & 4 & 5 & 6 & 7 & 8 & \\
\hline 1 & $\begin{array}{l}\text { Topical } \\
\text { Theme }\end{array}$ & 7 & 7 & 5 & 4 & 1 & 4 & $\begin{array}{l}1 \\
0\end{array}$ & 3 & 41 \\
\hline
\end{tabular}

\begin{tabular}{|l|c|c|c|c|c|c|c|c|c|c|}
\hline 2 & $\begin{array}{c}\text { Textual } \\
\text { Theme }\end{array}$ & - & - & 1 & 1 & 2 & 1 & - & - & 5 \\
\hline 3 & $\begin{array}{c}\text { Interpe } \\
\text { rsonal } \\
\text { Theme }\end{array}$ & - & - & - & - & - & - & 1 & - & 1 \\
\hline
\end{tabular}

After the numbers has found above the researcher want to scale in the percentage, the presented in the percentage is below:

Table 1.2 The percentage of theme rheme in Jokowi Widodo Speech.

\section{Theme}

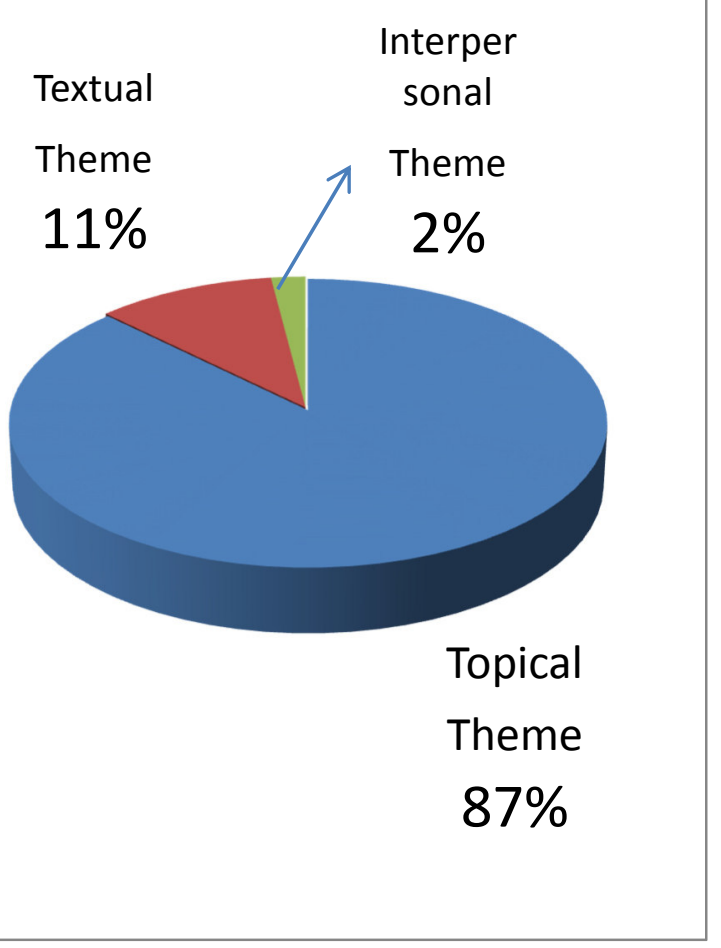

\section{DISCUSSION}

The most topical that appear on the speech text is topical theme. Topical theme is theme of clause ends with the constituent that is either participant, circumstance or subject. The function of topical theme is to emphasize the subject that the subject is the main goal of the speech text. The category of topical theme 
are included pronoun, adverbial, and nominal. In the speech text, the speaker often use it. Such as at the $1^{\text {st }}$ sentences in $1^{\text {st }}$ paragraphs.

The halal industries in the world as well as in Indonesia are growing so fast.

\begin{tabular}{|c|c|}
\hline THEME & RHEME \\
\hline TOPICAL & \\
\hline $\begin{array}{c}\text { The halal industries } \\
\text { in the world as well } \\
\text { as in Indonesia }\end{array}$ & Are growing so fast \\
\hline
\end{tabular}

And the second type is textual theme textual theme is Halliday and Matthiessen (2004) stated that textual theme is a theme that includes any combination of continuative (yes, no, well, oh, now), conjunctions (and, because, who, but, etc), conjunctive adjunct (for instance, in addition, likewise). Conjunctive adjuncts are allowed to move freely in a clause whereas conjunctions are constrained in the beginning (Giroux, 1997). In the speech text often found many word include in the textual theme was used in the speech text. Such as but, and, that, because, when, what, one by one, before, after and etc. like the one of sentence in $3^{\text {rd }}$ paragraph at $2^{\text {nd }}$ sentence:

.....and in 2020, it is projected to reach 158 million people.

\begin{tabular}{|c|c|c|}
\hline \multicolumn{2}{|c|}{ THEME } & RHEME \\
\hline TEXTUAL & TOPICAL & \\
\hline and & In 2020 & It is \\
& & projected to \\
& & reach 158 \\
& & million \\
& & people \\
\hline
\end{tabular}

And then, the third typical of theme is interpersonal theme. According to Paltridge (2006), interpersonal theme refers to an item that comes before rheme which indicates the relation between participants in the text, or the position or point of view that is being taken in the clause. This may include the finite in interrogative clause where it precedes the subject, vocative (personal name used to address), and mood adjuncts (surprisingly, in my opinion, unfortunately) (Halliday \& Matthiessen, 1994). In this speech text rarely to found the word that is included in interpersonal theme, it is 1 clauses that found in it. In this typical, word that found in the speech text such as American, politician, mother and children, never, finally and etc. Like the one of sentences has belong to interpersonal theme in 7 th paragraphs at 4th sentence:

Ms. Diajeng has stated that we have discussed this in one, two, or three meetings at the Palace.

\begin{tabular}{|c|c|}
\hline THEME & RHEME \\
\hline TOPICAL & \\
\hline Ms. Diajeng & $\begin{array}{c}\text { Has stated that we } \\
\text { have discussed this } \\
\text { in one, two, or three } \\
\text { meeting at the } \\
\text { Palace }\end{array}$ \\
\hline
\end{tabular}

\section{CONCLUSION}

A speech text that was utteranced by a president, makes importance to be discussed and understood what the fill of it. There for the researcher chooses the Jokowi Widodo's speech at the Halal Park Inauguration on 16 April 2019 at the Bung Karno Sports Complex. In this research has two statements of the problem, there are to find out the themes rheme and the kinds of theme rheme used in the speech text. After analyzing the speech, text can be seen that the result are 8 paragraphs existed in the website. From those eight paragraphs there are 47 clauses found: as a result, the researcher concludes that in the 47 clauses, there is $87 \%$ with 41 clauses belong to topical themes. Topical theme functions to

ISSN 15421-71667

Volume 2 Nomor 2 Desember 2019 
emphasize the subject is the main goal of the speech text. Then, the second is textual theme which the percentage is $11 \%$ of 5 themes. In this textual themes, they employ some coordinate conjunction, subordinate conjunction, correlation conjunction, and continuative conjunction, to connect the clauses one another such as but, and, that, because, when, what, one by one after etc. The last is interpersonal theme there are found 1 clauses which the percentage is $2 \%$.

\section{Reference}

Bloor \& Bloor 2004. The functional Analysis of English. New York: Oxford University Press

Giroux. 2007. Pedagogy and The Politics of Hope Theory, Culture, and Schooling. United States:

Westview Press

Halliday, M. A. K. 1994. An Introduction to Functional Grammar. London: Edward Arnold

Halliday, M. A. K., \& Matthiessen, C. M. I. 2004. An Introduction to Functional Grammar. London

Routledge.

Moleong, Lexy. (2002). Metodologi Penelitian Kualitatif. Bandung: PT. remaja Rosdakarya.

Moleong, Lexy J. (2007) Metodologi Penelitian Kualitatif, Penerbit PT Remaja Rosdakarya. Offset, Bandung.

Nancy Burns and Susan Grove. 2003. Understanding Nursing Research. Philadelphia: Saunders 